\title{
THE INFLUENCE OF EXTENSION ACTIVITIES ON THE COMPETENCIES OF TRADITIONAL FISHERIES PROCESSING IN LAMPUNG PROVINCE
}

\author{
Helvi Yanfika ${ }^{1^{*}}$, Siti Amanah ${ }^{2}$, Anna Fatchiya ${ }^{2}$, Pang S.Asngari ${ }^{2}$, \\ Abdul Mutolib ${ }^{1}$, Kordiyana K Rangga ${ }^{1}$ \\ ${ }^{1}$ Agricultural Extension Study Program, Faculty of Agriculture, Lampung University, \\ Bandar Lampung 35141 \\ ${ }^{2}$ Department of Communication Science and Community Development, \\ Faculty of Human Ecology, IPB University, Bogor 16688 \\ *Corresponding author: helviyanfika@yahoo.co.id \\ Accepted: March $6^{\text {th }}$ 2019/Approved: April $25^{\text {th }} 2020$
}

How to cite: Yanfika H, Amanah S, Fatchiya A, Asngari PS, Mutolib A, Rangga KK. 2020. Influence of extension activities on the competencies of traditional fisheries processing in Lampung Province. Jurnal Pengolahan Hasil Perikanan Indonesia. 23(1): 22-30.

\begin{abstract}
Extension is an informal learning process that plays an important role in improving fisheries processors competencies. However, current extension activities that have been running so far are felt to be lacking so it is necessary to look at the effectiveness of conducting extension on traditional fisheries business related to methods, media, materials and capabilities of extension agents. This study was aimed to (1) analyze the effectiveness of fisheries extension activities in traditional fisheries processing businesses in Lampung Province, (2) analyze traditional processors competency levels, (3) analyze the effect of extension on processors competencies/capabilities in traditional fisheries processing businesses. This study used a quantitative approach enriched with qualitative analysis. The survey was conducted to obtain primary data using a questionnaire. The research location were in three districts in Lampung Province. The data analysis technique used descriptive and regression analysis. The results of the study were (1) the effectiveness of extension was still low, (2) traditional processors competencies belonged to the low category, and (3) the ability of extension agents affected the development of fisheries processors' competencies. The effectiveness of extension is still low due to the limited extension methods. Therefore it is important to carry out extension activities with varied methods according to the target needs to improve the competency of traditional fisheries processors.
\end{abstract}

Keywords: competence, effectiveness, extension, traditional processors

\section{Pengaruh Penyuluhan terhadap Kompetensi Pengolah Perikanan Tradisional di Provinsi Lampung}

\begin{abstract}
Abstrak
Kompetensi pengolah perikanan tradisonal masih rendah sehingga perlu proses pembelajaran untuk meningkatkan kompetensi pengolah perikanan. Penyuluhan merupakan proses pembelajaran informal yang sangat berperan penting dalam meningkatkan kompetensi pengolah perikanan. Namun, kegiatan penyuluhan yang selama ini berjalan dirasakan kurang sehingga perlu dilihat efektivitas penyelenggaraan penyuluhan pada usaha perikanan tradisional terkait metode, media, materi, dan kemampuan penyuluh. Penelitian ini bertujuan (1) menganalisis efektivitas kegiatan penyuluhan perikanan pada usaha pengolahan perikanan tradisional di Provinsi Lampung, (2) menganalisis tingkat kompetensi pengolah tradisional, (3) menganalisis pengaruh penyuluhan terhadap kompetensi/kemampuan pengolah dalam usaha pegolahan perikanan tradisional. Penelitian ini menggunakan pendekatan kuantitatif dan diperkaya dengan analisis kualitatif. Survei dilakukan untuk memperoleh data primer menggunakan kuesioner. Lokasi penelitian berada pada tiga kabupaten di Provinsi Lampung. Teknik analisis data adalah deskriptif dan analisis regresi. Hasil penelitian memperlihatkan bahwa (1) efektivitas penyuluhan masih rendah, (2) kompetensi pengolah tradisional dalam kategori rendah, dan (3) kemampuan penyuluh berpengaruh terhadap pengembangan kompetensi pengolah perikanan. Efektivitas penyuluhan yang masih rendah disebabkan oleh metode penyuluhan yang terbatas pada metode ceramah, oleh karena itu penting untuk melakukan kegiatan penyuluhan dengan metode yang bervariasi sesuai kebutuhan sasaran dan dapat meningkatkan kompetensi pengolah perikanan tradisional.
\end{abstract}

Kata kunci: efektivitas, kompetensi, pengolah tradisional, penyuluhan 


\section{INTRODUCTION}

The amount of fisheries production reached 23,186,442 tonnes in 2017 including $7,071,452$ tonnes from capture fisheries and 16,114,991 tonnes from aquaculture (Ministry of Marine Affairs and Fisheries 2018). Fisheries production is processed in modern and traditional ways. Majority of the fisheries production are obtained through traditional ways to meet consumption demand (Junianingsih 2013). Of the 2.7 million fishermen, 95.6 percent of them are traditional fishermen operating around the coast (Asiati and Nawawi 2016). Traditional processors must produce quality processed products in order to compete with products that processed in a modern way.

Several studies suggest that the problems faced in traditional processing fishery products include the availability of raw materials (Talib 2018; Mutiara 2018), technology (Howara 2013; Mutolib et al. 2016; Asiati and Nawawi 2016; Hasyim and Ohoiwutun 2017), facilities and infrastructure (Marwan et al. 2013; Pitoy et al. 2017), and food additives in handling and processing raw materials (Yuliana et al. 2011; Devi et al. 2016), as well as product safety. These problems are related to both technical and managerial competencies of the processors in carrying out their business (Setiawan 2010; Listiana et al. 2019). Qualified technical and managerial competencies could improve the quality of products, resulting in sustainable traditional fisheries processing businesses (Yanfika et al. 2019; Rahayu and Adhi 2016).

Extension is one of the most important external factors in improving competence, because one's competency can be developed through training, seminars received in the extension activities. Fisheries extension needs to be well planned, to improve the ability of processors carrying out their business. Fisheries extension includes aspects of method, material, intensity, and role of extension agents (Amanah 2005; Fatchiya 2010). According to Huda (2010), fisheries extension agents must have the expected capabilities compatible to the characteristics of fish processors, as corroborated by Shinn et al. (2009). The technique of delivering information in fisheries extension needs to be improved combining different extension methods for enhancing knowledge transfer and improve learning in agriculture to increase the skills of processors, improving the welfare of traditional processors in Lampung Province. (Labarthe and Laurent 2013; Prager et al. 2016).

Thus, this research was conducted to (1) analyze the implementation of fisheries extension activities in traditional fisheries processing businesses in Lampung Province; (2) analyze traditional processors competency levels; and (3) analyze the influence of extension activities on the processors competencies/ capabilities in traditional fisheries processing businesses.

\section{MATERIAL AND METHOD}

The study was conducted by survey method in three districts in Lampung Province; namely Tanggamus, Pringsewu, and East Lampung Regencies on 2017. The population was traditional fisheries processors (salted, smoked, pemindangan (boiled salting) and fermentation) with a total of 570 processors. The number of samples was determined by the Slovin formula with an error rate of 5\%, thus 235 respondents were obtained. The number of samples in each group was determined using proportional random sampling technique (Sevilla et al. 1993).

The data include primary and secondary data. Primary information was obtained from traditional processors of fish salting, fish smoking, pemindangan, and fish fermentation. Information as a support for the main data was obtained from recording data that were available in offices and a number of agencies related to the research objectives.

Questionnaires were made in several forms including multiple choices questions that showed the ranking of answers, and statements with a Likert scale. On a questionnaire with a Likert Scale, each statement provided alternative answers that could be chosen by respondents in accordance with the understanding and experience that had been obtained (1, 2, 3 and 4 Scale).

\section{Data Analysis}

Technical data analysis uses descriptive 
and regression. The variables in this study are the method $\left(\mathrm{X}_{1}\right)$, media $\left(\mathrm{X}_{2}\right)$, material $\left(\mathrm{X}_{3}\right)$, the ability of the extension agent $\left(\mathrm{X}_{4}\right)$, and the processors competency $(\mathrm{Y})$.

$\mathrm{Y}=\mathrm{f}\left(\mathrm{X}_{1}, \mathrm{X}_{2}, \mathrm{X}_{3}, \mathrm{X}_{4}\right) \ldots$. equation of regression Information:

Y: dependent variable

$\mathrm{f}$ : function

$\mathrm{X}$ : independent variable

\section{RESULTS AND DISCUSSION}

In general, processors gave low rating on the category of extension services. It is suggest that the outcome of extension activities did not reach the processors in three districts of the research location (Yanfika et al. 2018). Field assessment showed the pemindang processors in Pringsewu Regency rarely receive extension activies. In contrast, East Lampung Regency and Tanggamus Regency often receive extension activities. The extension activities were still carried out through top down manner. This system is one of the causes of existing extension has not been able to change the behavior and capabilities of traditional processors in carrying out their business (Amanah 2005; Fatchiya 2010; Helmy 2013; Yuliana et al. 2011; Sapar et al. 2012)

The method used in the extension activities was considered unsuitable. Lecture is the only method used during extension activities, while practices or demonstrations are rarely carried out. Traditional fisheries processors consider the self-practice or demonstration very important regarding transfer of knowledge. The use of media in the extension activities was considered inadequate, limited to the use of laptops and LCDs only. The instructor should be able to deliver the material using various types of media. When instructors use Laptops and LCDs, it is better to present pictures/photos, films, booklets, leaflets. (Ruyadi et al. 2017). Since most of the respondents already used mobile phones, it makes sense for extension agents to transfer innovations using electronic media (Anwas et al. 2010; Muntoha et al. 2015). The findings of research are in line with Christian and Subejo (2018)which stated that the use of technology and media is related to the success of extension process.
Materials presented during extension activities were not suitable with the needs of traditional fisheries processors. The materials presented by the instructors were about finance, marketing, and group development, while the traditional fisheries processors need information about good and quality fish processing methods. This gap means that the material received by the processor could not solve the traditional processser problems. This is in line with the results of the study of Asta et al. (2015) which stated that extension materials must be able to meet the needs of farmers. The processors expect the material presented not only in written form, but also using films or photographs that can support the writing.

The respondents considered the extension agents capable in delivering the extenstion activities. The agents also have good communication skills so that the material delivered by extension agents can be well received by the participants of the extension activities. Some traditional fisheries processors stated that the extension agents understand the material by answering questions from traditional fisheries processors and can explain very well, helping the processors to solve problems, make decisions, facilitate processors in finding customers, finding information, and establish relationships with business partners.

\section{The Competencies of Traditional Fisheries Processors}

The $89.8 \%$ of the traditional fisheries processors were considered having low technical competency. Meanwhile, $73.6 \%$ of the processors hadlow managerial competency. Nevertheless, the social competency of the traditional fisheries processing competencies were mostly in high category (62.6\%) (Table 2).

The results of Mann Whitney's different test analysis found that there were no differences in technical and social competencies from the three districts, while managerial competencies in the three districts indicated different competencies. This could be observed from the value of Asymp. Sig. (2-tailed) obtained which greater than 
Table 1 Assessment of traditional fisheries processors on the implementation extension in Lampung

\begin{tabular}{|c|c|c|c|c|c|c|}
\hline \multirow[b]{2}{*}{ Variables/Category } & \multicolumn{2}{|c|}{ Tanggamus } & \multicolumn{2}{|c|}{ Pringsewu } & \multicolumn{2}{|c|}{ East Lampung } \\
\hline & $\begin{array}{c}\text { Number of } \\
\text { Response }\end{array}$ & $\%$ & $\begin{array}{c}\text { Number of } \\
\text { Response }\end{array}$ & $\%$ & $\begin{array}{c}\text { Number of } \\
\text { Response }\end{array}$ & $\%$ \\
\hline \multicolumn{7}{|l|}{ Method } \\
\hline Less Appropriate & 43 & 72.89 & 53 & 96.37 & 83 & 68.60 \\
\hline Appropriate & 16 & 27.11 & 2 & 3.63 & 38 & 31.40 \\
\hline Total & 59 & 100.00 & 55 & 100.00 & 121 & 100.00 \\
\hline Average & $\begin{array}{c}4.19 \\
\text { (Less Relevant) }\end{array}$ & & & & & \\
\hline Standard Deviation & 0.45 & & & & & \\
\hline \multicolumn{7}{|l|}{ Media } \\
\hline Less Appropriate & 49 & 83.05 & 52 & 94.55 & 69 & 58.71 \\
\hline Appropriate & 10 & 16.95 & 3 & 5.45 & 50 & 41.32 \\
\hline Total & 59 & 100.00 & 55 & 100.00 & 121 & 100.00 \\
\hline Average & $\begin{array}{c}4.02 \\
\text { (Less Relevant) }\end{array}$ & & & & & \\
\hline Standard Deviation & 0.73 & & & & & \\
\hline \multicolumn{7}{|l|}{ Material } \\
\hline Less Appropriate & 47 & 79.66 & 55 & 100.00 & 86 & 71.07 \\
\hline Appropriate & 12 & 20.34 & 0 & 0 & 35 & 28.93 \\
\hline Total & 59 & 100.00 & 55 & 100.00 & 121 & 100.00 \\
\hline Average & $\begin{array}{c}4.20 \\
\text { (Less Relevant) }\end{array}$ & & & & & \\
\hline Standard Deviation & 0.41 & & & & & \\
\hline \multicolumn{7}{|l|}{ Extension Ability } \\
\hline Less Capable & 7 & 11.86 & 0 & 0 & 0 & 0 \\
\hline Capable & 36 & 77.96 & 52 & 94.55 & 101 & 83.47 \\
\hline Very Capable & 6 & 10.17 & 3 & 5.45 & 20 & 16.53 \\
\hline Total & 59 & 100.00 & 55 & 100.00 & 121 & 100.00 \\
\hline Average & $\begin{array}{c}22.47 \\
\text { (Capable) }\end{array}$ & & & & & \\
\hline Standard Deviation & 3.88 & & & & & \\
\hline
\end{tabular}

0.005 and 0.001 , it means that there was no difference between competency of processors at Tanggamus, Pringsewu and Lampung. The lowest competency were observed in processors in Tanggamus Regency, followed by Pringsewu Regency, while East Lampung Regency was better than the other districts. Since East Lampung Regency is the center of fisheries and fisheries processor, the traditional fisheries processor in the region often receive training from the provincial/district fisheries service and Lampung University.

\section{Technical Competence}

Distribution of respondents based on technical competency can be seen in Table 3. Almost all of fish processors used fish of different size, and do not use illegal additives, but some processors add flavoring ingredients such as turmeric, lemongrass, and bay-leaf especially in processors of pindang tuna in Pringsewu Regency. This practice is conducted to produce pindang which have pleasant smell and taste, while most traditional fish processors only use salt. 
Table 2 Competencies of traditional fisheries processors in Lampung Province

\begin{tabular}{|c|c|c|c|c|c|c|c|c|}
\hline \multirow[b]{2}{*}{ Variables/Category } & \multicolumn{2}{|c|}{ Tanggamus } & \multicolumn{2}{|c|}{ Pringsewu } & \multicolumn{2}{|c|}{ East Lampung } & \multirow[b]{2}{*}{ Total } & \multirow[b]{2}{*}{$\%$} \\
\hline & $\begin{array}{c}\text { Number of } \\
\text { Response }\end{array}$ & $\%$ & $\begin{array}{c}\text { Number } \\
\text { of } \\
\text { Response }\end{array}$ & $\%$ & $\begin{array}{c}\text { Number } \\
\text { of } \\
\text { Response }\end{array}$ & $\%$ & & \\
\hline \multicolumn{9}{|l|}{ Technical Competence } \\
\hline Very low (0-25) & 16 & 27.1 & 0 & 0.0 & 4 & 3.3 & 23 & 9.8 \\
\hline Low (25.1-50) & 43 & 72.9 & 55 & 100.0 & 79 & 65.3 & 211 & 89.8 \\
\hline High (50.1-75) & 0 & 0.0 & 0 & 0.0 & 37 & 30.6 & 1 & 0.4 \\
\hline Very high (75.1-100) & 0 & 0.0 & 0 & 0.0 & 0 & 0.0 & 0 & 0.0 \\
\hline \multicolumn{9}{|l|}{ Average (30.5) } \\
\hline \multicolumn{9}{|l|}{ Standard Deviation (4.3) } \\
\hline \multicolumn{9}{|l|}{ Managerial Competence } \\
\hline Very low (0-25) & 14 & 23.7 & 7 & 12.7 & 12 & 9.9 & 33 & 14.0 \\
\hline Low $(25.1-50)$ & 39 & 66.1 & 48 & 87.3 & 86 & 71.1 & 173 & 73.6 \\
\hline High (50.1-75) & 6 & 10.2 & 0 & 0.0 & 23 & 19.0 & 29 & 12.3 \\
\hline Very high (75.1-100) & 0 & 0.0 & 0 & 0.0 & 0 & 0.0 & 0 & 0.0 \\
\hline \multicolumn{9}{|l|}{ Average (36.5) } \\
\hline \multicolumn{9}{|l|}{ Standard Deviation (11.4) } \\
\hline \multicolumn{9}{|l|}{ Social Competence } \\
\hline Very low (0-25) & 0 & 0.0 & 0 & 0.0 & 0 & 0.0 & 0 & 0.0 \\
\hline Low $(25.1-50)$ & 22 & 37.3 & 52 & 94,5 & 0 & 0.0 & 74 & 31,5 \\
\hline High (50.1-75) & 24 & 40.7 & 3 & 5,5 & 120 & 99,2 & 147 & 62.6 \\
\hline Very high (75.1-100) & 13 & 22.0 & 0 & 0.0 & 1 & 0.8 & 14 & 6.0 \\
\hline \multicolumn{9}{|l|}{ Average (56.1) } \\
\hline Standard Deviation (14 & & & & & & & & \\
\hline
\end{tabular}

The results of the observation showed that almost all production sites were safe from pollution, near to clean water supply, has a sewage channel, and accessible. The building where the business is located was easy to clean, even though most of the business premises are in residencial area. The building where the production located also has lighting that tends to be dark. Traditional fisheries processors have used the equipments that were not easily corroded, do not absorb water, and were easy to clean. Processors have arranged the equipment properly, but some of them have not compiled their equipment. They also had separated the equipment used for production, waste, and other materials.

Sanitation used for production has an important role in the production activities. More than $50 \%$ of clean water sanitation is in good condition and in accordance with drinking water standards. It also comes from non-hazardous sources. However, packing and labelling was still use wax. Processors have not used packing machines, packaging labels, and did not include halal labels and materials used. Their still use motorcycles to distribute their products and never separate processed products with other products when transporting. Product separation were found in salting businesses using cars and the products were sent out of the regency and province.

\section{Managerial Competence}

Managerial competencies were include (1) arrangements for determining workforce duties; (2) finance; (3) total production; (4) product marketing; and (5) product diversification. Traditional processing managerial competencies of fisheries was categorized into low category because most processors have not conducted management functions. Some processors delegate the work to the employees, but did not educate the 
Table 3 Distribution of respondents based on technical competence in Lampung Province

\begin{tabular}{|c|c|c|c|c|}
\hline \multirow{2}{*}{ Technical Competence } & \multicolumn{4}{|c|}{ Categories } \\
\hline & Very Low & Low & High & Very High \\
\hline \multicolumn{5}{|l|}{ Selection of raw materials } \\
\hline a. Using legal additional material & 0.0 & 1.7 & 98.3 & 27.2 \\
\hline b. Using flavor ingredients & 9.8 & 47.2 & 15.7 & 0.0 \\
\hline \multicolumn{5}{|l|}{ Location and building } \\
\hline a. The location is not polluted & 9.4 & 90.2 & 0.4 & 0.0 \\
\hline b. The availability of clean water & 13.2 & 86.4 & 0.4 & 0.0 \\
\hline c. The availability of sewage system & 11.5 & 88.1 & 0.4 & 0.0 \\
\hline $\mathrm{d}$. The location is accessible & 3.4 & 96.2 & 0.4 & 0.0 \\
\hline e. The location is easy to clean & 6.8 & 48.5 & 44.7 & 0.0 \\
\hline $\mathrm{f}$. The building is separated with house & 48.9 & 49.4 & 1.7 & 0.0 \\
\hline g. The building has sufficient lighting & 46.0 & 37.9 & 16.2 & 0.0 \\
\hline \multicolumn{5}{|l|}{ Equipment and supplies } \\
\hline $\begin{array}{l}\text { a. Equipment and supplies are not easily rusted, does not absorb water } \\
\text { and easy to clean }\end{array}$ & 17.9 & 36.6 & 45.1 & 0.4 \\
\hline b. Equipments are well-arranged and organized & 6.4 & 46.0 & 47.7 & 0.0 \\
\hline $\begin{array}{l}\text { c. Equipments are separated for production, waste, and miscellaneous } \\
\text { purposes }\end{array}$ & 5.5 & 47.2 & 47.2 & 0.0 \\
\hline d. Availability of water for drink and other purposes & 6.8 & 15.7 & 71.1 & 6.4 \\
\hline $\begin{array}{l}\text { e. The source of water from non hazardous source, water pipes are } \\
\text { designed to avoid contamination with dirty water }\end{array}$ & 17.5 & 81.7 & 0.9 & 0.0 \\
\hline \multicolumn{5}{|l|}{ Packing and labeling } \\
\hline a. Using a flap machine & 0.0 & 95.7 & 4.3 & 0.0 \\
\hline b. Using a label in packaging & 0.0 & 96.2 & 3.8 & 0.0 \\
\hline c. Include halal and ingredient labels & 0.0 & 98.7 & 1.3 & 0.0 \\
\hline \multicolumn{5}{|l|}{ Distribution } \\
\hline a. The product is safely distributed & 57.9 & 30.6 & 11.5 & 0.0 \\
\hline b. Each product distributed separately with other product & 48.5 & 10.6 & 32.3 & 8.5 \\
\hline \multicolumn{5}{|l|}{ Control or check during production } \\
\hline Control of time to maintain product quality & 0.0 & 0.0 & 100.0 & 0.0 \\
\hline
\end{tabular}

ability of the new employees. In the financial sector, most processors have recorded the circulation of money, and separate business and personal finances, but there were still a large number of processors who have not recorded the financial business and have not separated the business and personal finances (Table 4). In production section, the processor checked the quantity of product stock, but most processors did not check the remaining product.

Most traditional fisheries processors in Pringsewu Regency did not provide holiday allowance to their employees. It is different from fisheries processors in Tanggamus
Regency and East Lampung Regency who provide holiday allowance to their employees. Processors carried out promotions to introduce their products by participating in exhibitions or bazaars. Traditional fisheries processors in Tanggamus Regency, Pringsewu Regency and East Lampung Regency sold their products to other districts or to Bandar Lampung. Processors in Tanggamus and Pringsewu Regencies rarely offered special prices, while traditional East Lampung Regency processors often offered special prices if the consumers buy in large quantities. Most processors rarely produced variations in size (Table 4). 
Table 4 Distribution of respondents based on managerial competence in Lampung Province

\begin{tabular}{lcccc}
\hline \multirow{2}{*}{\multicolumn{1}{c}{ Managerial Competence }} & \multicolumn{4}{c}{ Categories } \\
\cline { 2 - 5 } & Very Low & Low & High & Very High \\
\hline Consider new worker abilities & 27.2 & 48.1 & 24.7 & 0.0 \\
Define tasks by ability & 0.0 & 26.8 & 73.2 & 0.0 \\
Record financial business & 33.2 & 34.9 & 31.9 & 0.0 \\
Separate between business and personal finances & 32.8 & 37.0 & 30.2 & 0.0 \\
Check the stock of product in shop before production & 25.1 & 37.0 & 29.8 & 8.1 \\
Give holiday allowance for employee & 26.8 & 43.8 & 29.4 & 0.0 \\
Check processed results before the market & 2.1 & 17.0 & 32.3 & 48.5 \\
Join bazaar event to promote the product & 0.0 & 88.1 & 11.9 & 0.0 \\
Record sales of products & 47.7 & 41.7 & 10.2 & 0.4 \\
Special pricing for purchasing large quantities & 11.5 & 48.1 & 37.0 & 3.4 \\
Create product with size variations & 3.4 & 41.3 & 19.2 & 36.2 \\
\hline
\end{tabular}

\section{Social Competence}

Social competencies of traditional fisheries processors were includes the attitude of processors to other processors in terms of raw material supply, similarity in product selling prices, the rising of new competitors and criticism as well as suggestions that arise for products that produced. Participation of the processor in gathering or meeting was low (low category with 46.0\%). Processors help each other if there is a shortage of raw materials, if the processor has excess fish to be processed then they share it with processors that do not have fish (high category with 78.7 percent). Due to the higher demand of processed fisheries products, it is no doubt of the emerging of new competitor in the sector. Processors in Tanggamus Regency, Pringsewu Regency and East Lampung Regency were ready to compete with new competitors. The processors have prepared to accept criticism of the products. Most processors in Tanggamus Regency, Pringsewu Regency and all processors in East Lampung Regency improved their products in accordance with the criticism and suggestions received.

\section{Effect of Extension Effectiveness on Competence of Fisheries Processors}

Extension is a learning process to improve the knowledge, attitudes and skills of processors so that the processors have high competency. Field facts showed that fisheries processors competencies were influenced by the ability of extension agent. The extension agent ability influenced competency development with the value of $\beta=0.505$, $\mathrm{t}$-value $=8.644$ with a significance of $0,0001^{* *}$ (at the level of confidence of 99 percent), while the method, media and material did not affect the competencies.

\section{CONCLUSION}

The implementation of extension on traditional fisheries product processor was still not effective, as seen from the methods of extension, media and material that were not suitable for traditional processors. Traditional

Table 5 Distribution of respondents based on social competence in Lampung Province

\begin{tabular}{lcccc}
\hline \multirow{2}{*}{ Social Competence } & \multicolumn{4}{c}{ Categories } \\
\cline { 2 - 5 } & Very Low & Low & High & Very High \\
\hline Attends meetings in the area & 1.7 & 46.0 & 40.0 & 12.3 \\
Share the raw materials with another processors & 12.8 & 78.7 & 8.5 & 0.0 \\
Tolerance to anothers processors that reduce the price & 0.4 & 34.5 & 65.1 & 0.0 \\
Readiness to face a new competitor & 0.4 & 0.4 & 77.9 & 21.3 \\
Welcome to criticism or suggestions of the product & 31.1 & 3.4 & 1.3 & 64.3 \\
\hline
\end{tabular}


fisheries processor competencies were still low, especially in technical and managerial competencies, while traditional fisheries processor social competencies were at a high level. Factor that influence the improvement of fisheries processing competencies was the ability of extension agents. The extension agents ability needs to modify methods, media and extension materials to attract the fisheries product processors and also meet the processors need.

\section{ACKNOWLEDGMENT}

The author expresses her gratitude to the Fisheries and Marine Service of Lampung Province, East Lampung Fisheries and Animal Husbandry Office, Fisheries Service Office of Pringsewu Regency, and Fisheries and Marine Service Office of Tanggamus Regency who helped in the process of collecting research data and information.

\section{REFERENCES}

Amanah S. 2005. Pengembangan masyarakat pesisir berdasarkan kearifan lokal di pesisir Kabupaten Buleleng di Provinsi Bali. [Disertasi]. Bogor (ID): Institut Pertanian Bogor.

Anwas EOM, Sumardjo S, Asngari PS, Tjitropranoto P. 2010. Model pengembangan kompetensi penyuluh berbasis pemanfaatan media (Kasus di Kabupaten Karawang dan Garut, Provinsi Jawa Barat). Jurnal Penyuluhan. 6(1): 1-10.

Asiati D, Nawawi. 2017. Partnership in the fishery sector: Strategies for business and employment sustainability. Jurnal Kependudukan Indonesia. 11(2): 103-118.

Asta DU, Hubeis AVS, Fatchiya A. 2015. Kapasitas petani kakao bekas penambang batu bara di Kota Sawahlunto Sumatera Barat. Jurnal Penyuluhan. 11(2): 1-16.

Christian AI, Subejo S. Akses, fungsi, dan pola penggunaan teknologi informasi dan komunikasi (TIK) oleh petani pada kawasan pertanian komersial di Kabupaten Bantul. Journal of Social and Agricultural Economics. 11(1): 25-30.

Devi KPT, Suamba IK, Artini NWP. 2016. Analisis pengendalian mutu pada pengolahan ikan palagis beku. Jurnal Agribisnis dan Agrowisata. 5(1):1-11.

Fatchiya A. 2010. Tingkat kapasitas pembudi daya ikan dalam mengelola usaha akuakultur secara berkelanjutan. Jurnal Penyuluhan. 6(1): 67-75.

Hasyim CL, Ohoiwutun EC. 2017. The role of communication on traditional fisherman empowerment at the coastal communities (PMP) in Southeast Maluku. Jurnal Penelitian Komunikasi dan Pembangunan. 18(1): 31-42.

Helmi Z, Sumardjo, Purnaningsih N, Tjitropranoto P. 2013. Hubungan kompetensi penyuluh dengan karakteristik pribadi, persepsi penyuluh terhadap dukungan kelembagaan dan persepsi penyuluh terhadap sifat inovasi cyber extension. Jurnal Agro Ekonomi. 31(1): 1-18

Howara D. 2013. Strategi pengembangan pengolahan hasil perikanan di Kabupaten Donggala. Jurnal Agroland. 17(3):75 - 81.

Huda N. 2010. Kompetensi penyuluh dalam mengakses informasi pertanian: Kasus alumni UT di Serang. Jurnal Matematika, Sains, dan Teknologi. 11(1):65-77.

Junianingsih I. 2013. Analisis profitabilitas usaha pengolahan tradisional ikan tongkol asap di Desa Jangkar Kabupaten Situbondo. Samakia: Jurnal Ilmu Perikanan. 4(2): 86-93.

Labarthe P, Laurent C. 2013. Privatization of agricultural extension services in the EU: Towards a lack of adequate knowledge for small-scale farms? Food Policy. 38: 240252.

Listiana I, Efendi I, Mutolib A, Rahmat A. 2019. The behavior of extension agents in utilizing information and technology to improve the performance of extension agents in Lampung Province. Journal of Physics: Conf. Series 1155012004.

Marwan UM, Wiryawan B, Lubis E. 2013. Kajian strategi pengembangan industri pengolahan ikan di Kota Palopo Provinsi Sulawesi Selatan. Jurnal Teknologi Perikanan dan Kelautan. 4(2): 197-209.

Ministry of Marine Affairs and Fisheries. 2018. Marine and Fisheries in Figures 2018. [downloaded 2019 Jul 25]. Available 
at:https://kkp.go.id/setjen/satudata/ page/1453-kelautan-dan-perikanandalam-angka.

Muntoha J, Jamroni J, Putra MAW. 2015. Penyuluhan literasi media internet dan telepon genggam di Dusun Bandung dan Dusun Songbanyu 1, Desa Songbanyu, Kecamatan Giri Subo, Gunung Kidul, Daerah Istimewa Yogyakarta. Jurnal Inovasi dan Kewirausahaan. 4(2): 149154.

Mutiara TK, Wibowotomo B, Issutarti, Wahyuni W. $2018 . \quad$ Diversifikasi pengolahan produk perikanan bagi kelompok nelayan di Kabupaten. Jurnal Karinov. 1(1): 1-12.

Mutolib A, Yonariza Y, Mahdi M, Ismono H. 2016. Gender inequality and the oppression of women within minangkabau matrilineal society: A case study of the management of ulayat forest land in Nagari Bonjol, Dharmasraya District, West Sumatra Province, Indonesia. Asian Women. 32 (3): 23-49.

Pitoy CR, Jan ABH, Karuntu MM. 2017. Perencanaan kualitas pada produksi ikan asap (studi kasus di Desa Minaesa Kecamatan Wori Kabupaten Minahasa Utara). Jurnal EMBA: Jurnal Riset Ekonomi, Manajemen, Bisnis dan Akuntansi. 5(2): 829-835.

Prager K, Labarthe P, Caggiano M, Lorenzo-Arribas A. 2016. How does commercialisation impact on the provision of farm advisory services? evidence from Belgium, Italy, Ireland and the UK. Land Use Policy. 52:329-344.

Rahayu WP, Adhi W. 2016. Penerapan good logistic practices untuk produk perikanan. Jurnal Manajemen Transportasi dan Logistik. 3(2): 129-147.

Ruyadi I, Winoto Y , Komariah N. 2017. Media komunikasi dan informasi dalam menunjang kegiatan penyuluhan pertanian. Jurnal Kajian Informasi \& Perpustakaan. 5(1): 37-50.
Sapar A, Jahi PS, Asngari PS, Putupurnaba IG. 2012. Kinerja penyuluh pertanian dan dampaknya pada kompetensi petani kakao di empat wilayah Sulawesi Selatan. Jurnal Penyuluhan. 8(1):29-41.

Setiawan W. 2010. Kompetensi sumberdaya manusia dalam upaya pemanfaatan potensi kelautan di Kabupaten Tasikmalaya. Jurnal Perencanaan Wilayah dan Kota. 2(1): 69-80.

Sevilla CG, Ochave JA, Regala BP, Uriarte GG. 1993. Pengantar metode penelitian : An introduction to research methods. Diterjemahkan oleh Alimuddin Tuwu. Jakarta: University of Indonesia press.

Shinn GC, Wingenbach GJ, Lindner JR, Bries GE, Baker M. 2009. Redefining agricultural and extension education as a field of study: consensus of fifteen engaged international Scholars. Journal of International Agricultural and Extension Education. 16(1): 73-88.

Talib A. 2018. Peluang dan tantangan industri teknologi pengolahan hasil perikanan dalam mendukung terwujudnya lumbung ikan nasional (LIN) di Maluku Utara. Agrikan: Jurnal Agribisnis Perikanan 11(1): 19-27.

Yanfika H, Amanah S, Fatchiya A, Asngari PS. 2018. Strategy to Develop Traditional Fishery Business in Implementing the Principle of Sustainable Business. Jurnal Penyuluhan. 14(2): 271-280.

Yanfika H, Listiana I, Mutolib A, Rahmat A. 2019. Linkages between extension institutions and stakeholders in the development of sustainable fisheries in Lampung Province. Journal of Physics: Conf. Series 1155012014.

Yuliana E, Suhardi DA, Susilo A. 2011. Tingkat penggunaan bahan kimia berbahaya pada pengolahan ikan asin: kasus di Muara Angke dan Cilincing, Jakarta. Jurnal Pengolahan Hasil Perikanan Indonesia. 14(1):14-21. 